\title{
EURODELFOITUTKIMUS SUOMEN AIKUISKOULUTUKSESTA
}

\section{Tämän vuosikymmenen alussa käynnistyi Belgiassa aikuiskoulutusta koskeva delfoityyppinen tutkimusprojekti, joka laajeni 17 Euroopan maata käsittäväksi, vertailevaksi tutkimukseksi. Kun Suomesta tuli EU:n jäsen, projekti käynnistettiin myös meillä. Kirjoittajat raportoivat artikkelissaan keväällä 1996 kerätyn tutkimusaineiston tuloksia.}

Artikkeli esittelee elinikäisen oppimisen vuoden ohjelmaan kuuluneen Eurodelfoihankkeen Suomen asiantuntijakyselyn tuloksia. Hanke on 17 Euroopan maan tai alueen yhteinen aikuiskoulutuspolitiikkaa vertaileva ja kehittävä tutkimus. Se käynnistyi vuonna 1990 Belgian flaaminkielisellä alueella ja laajeni 1993 eurooppalaiseksi projektiksi (ks. tarkemmin Leirman 1995 Eurodelphi 95 - Future Goals and Policies of Adult Education in Europe). Suomessa Eurodelfoi käynnistettiin 1995. Artikkelissa esiteltävä aineisto on kerätty keväällä 1996 ja esitelty laajemmin Suomen maaraportissa (Nurmi \& Kontiainen \& Tissari 1996).

Suomen Eurodelfoitutkimus toteutetaan Helsingin yliopiston kasvatustieteen laitoksella. Tutkimuksen koordinaattoreina toimivat professori Seppo Kontiainen ja apulaisprofessori Kari E. Nurmi ja projektin tutkijana kasvatustieteen ylioppilas Varpu Tissari. Suomen Eurodelfoitutkimukselle on asetettu kentän asiantuntemusta edustava johtoryhmä, joka on ohjannut tutkimukseen osallistuvien asiantuntijoiden valintaa ja koko eurodelfoitutkimuksen prosessia. Suomen Eurodelfoitutkimus liittyy sisällöllisesti Helsingin yliopiston kasvatustieteen laitoksella vuonna 1995 käynnistyneeseen koulutuksen vaikuttavuusprojektiin, joka puolestaan on osa Suomen Akatemian koulutuksen vaikuttavuus -tutkimusohjelmaa vuosille 1995 - 1998.

Koulutuspolitiikkaan kohdistuva vertaileva tutkimus on harvinaista eikä sille ole vakiintunut selkeätä paradigmaa. Vertaileva kasvatustiede on ollut suhteellisen erillään valtio-opillisesta politiikan tutkimuksesta. Viimeksi mainitun piirissä taas koulutus on ollut marginaalinen teema, joka sisältyy pääasiassa hyvinvointivaltioproblematiikkaan (näin esim. Hague \& Harrop \& Breslin 1992, 409 - 414 et passim). Kehittämispyrkimykset (esim. Lane \& Ersson 1994, 89-98) eivät ole muuttaneet tilannetta. Toiminta-alueena koulutuspolitiikka on luonteeltaan politiikan kansainvälisimpiä, tutkimuskohteena sen syrjäytyneimpiä alueita. Valtaosa tutkimuksista on Eurodelfoitutkimuksen tapaisia hankkeita, joissa tutkimusta ohjaa välitön käytännöllinen soveltamisintressi. Kasvatusta tai koulutusjärjestelmää ei tarkastella selitystä vaativina ilmiöinä, vaan yhteistyössä ja kilpaillen tapahtuvan kehittämisen kohteena. Vertaileva kasvatustiede taas ei ole löytänyt aikuiskasvatusta, vaan julkaistu kirjallisuus (esim. Jarvis 1992) on sen osalta joko historiallista tai maakohtaista tarkastelua.

Eurodelfoihin omaksuttu lähestymistapa on ohjatun koulutusfuturologisen keskusteluprosessin virittäminen. Pyrkimyksenä on saada 
yhteiskunnan koulutusjärjestelmä ja poliittinen järjestelmä keskusteluun, jossa tulevaisuudenpolkujen halkoma aika ja avaruus voitaisiin haarukoida astetta realistisemmin kuin viime vuosikymmenellä. Kohteesta, jota tilastolliset tunnusluvut esittävät kapeasti ja jälkijättöisesti, välitetään asiantuntijoiden osin intuitiivisestikin hahmottama käsitys. Tieteellisesti menettely on havooittuva ja kritiikille altis, mutta eri maiden asiantuntijoiden käsitysten vertailu tuo siihen kuitenkin mielipidemuoteja syvempää mielenkiintoa.

Eurodelfoi liittyy toisaalta elinikäisen oppimisen, toisaalta oppivan organisaation/alueen/ maan koulutusideologioihin. Se etsii koulutuspolitiikkaa, joka loisi edellytykset kansalaisten omaehtoiselle, koko elinkaaren kattavalle monipuolisesti hyödynnettävälle oppimiselle. Samalla se pyrkii tavoittamaan oppimisen kollektiivista ulottuvuutta, jossa yksilöllisesti tapahtuva oppiminen saisi tarvitsemaansa tukea ja tulisi myös yhteiseen synergiakäyttöön. EU:n läheisyysperiaate edellyttää, että yhteinenkin oppiminen aina mukautuu alueellisiin ratkaisuihin ja palvelee täysimittaisesti paikallisia tarkoitusperiä. Tämän lähtökohdan mukaisesti asiantuntijoille kyselylomakkeella esitetty yhteiskunnan ja koulutusjärjestelmän hahmotelma jakaantuu ihmisten kokemiin ongelmiin, niiden ratkaisumahdollisuuksiin koulutuksen keinoin, koulutukselle asetettaviin tavoitteisiin ja koulutukseen käytettäviin voimavaroihin sekä alueen aktuaalista koulutuspolitiikkaa koskevaan osaan, jossa huomioidaan sekä poliittiset elimet tehtävineen että kunkin alueen koulutuslainsäädäntö. Koulutuspolitiikan eurooppalainen ulottuvuus esitetään vain osana tätä kokonaisuutta.

Eurodelfoin ensimmäinen vaihe perustuu asiantuntijoiden edellä esitetyn järjestelmäkokonaisuuden mukaiselle kyselylomakkeelle antamiin vastauksiin. Lomake tuo aineistoon vertailtavuuden, mutta samalla tietysti myös peittää vastaajien aikuiskasvatusta koskevien käsitysten välisiä eroja. Teoreettiselta kannalta kyselyn kohteena on asiantuntijan aikuiskasvatuskäsitys, mutta kuitenkin Eurodelfoin järjestel- mäkehikkoon sovitettuna. Kehikon toimivuus riippuu yhtäältä alkuperäisen belgialaisen konseption siirrettävyydestä muihin Euroopan maihin ja toisaalta lomakkeen alunperin flaaminkielisten ilmaisujen kääntämisen onnistumisesta englanniksi ja myöhemmin kaikille Eurodelfoitutkimuksen toteuttaneiden maiden/alueiden äidinkielille.

\section{Delfoitekniikka ja tutkimuksen vaiheet}

Delfoitekniikka on asiantuntijoiden kuulemiseen luotu menetelmä, jolla alunperin selvitettiin pääasiassa sitä, milloin tiettyjen asioiden voidaan odottaa tulevaisuudessa toteutuvan. Tekniikan keskeisiä piirteitä ovat 1) riittävän suuren, mutta kuitenkin kohtuulliseksi jäävän asiantuntijapaneelin käyttäminen arvioitsijoina, 2) arviointiprosessin toistaminen kolmena aaltona siten, että asiantuntijoille palautetaan toistuvasti koko ryhmän tulokset ja tarjotaan sen jälkeen mahdollisuus uuteen arviointiin, sekä 3) sellaisten suhteellisen yksiselitteisten kysymysten käyttäminen, joiden vastaukset voidaan ilman liian monia varauksia koota eräänlaiseksi Delfoin Pythian oraakkeli-vastaukseksi. (Sackman 1975.)

Tulevaisuutta ei voi tutkia, ennen kuin se on toteutunut, eikä se silloin enää ole tulevaisuutta. Sen vuoksi on perusteltua kysyä asiantuntijoiden näkemyksiä, olkoonkin, että ne kertovat enemmän nykyisyydestä. Epäjatkuvakin tulevaisuus rakentuu jollakin tavoin nykyisyyden varaan, joten tulevaisuuteen vaikuttavien ihmisten käsitysten tuntemisella voi olla merkitystä tulevaisuutta toteutettaessa. Tämä on vielä ilmeisempää, kun kysymys on oudoista ihmisistä, kuten Eurodelfoitutkimuksessa 16 meille vieraan Euroopan maan aikuiskasvatuksen asiantuntijat ovat. Tutkimusaineisto tarjoaa mahdollisuuden verrata eri maiden asiantuntijoiden käsityksiä ja tuottaa siten uutta tietoa, vaikka se ei kerrokaan, millainen aikuiskasvatuksen tulevaisuus on.

Eurodelfoitutkimuksen tiedonkeruu on systee- 
mistä palautetta, jolla yhteiskunnallisille päätöksentekijöille ja muille asiantuntijoille tuotetaan nykyhetkeä ja odotettua tulevaisuutta koskevaa informaatiota. Tutkimukseen osallistuneet asiantuntijat ovat itse osa sitä joukkoa, joille informaatio on tarkoitettu. Toistuva tutkimusprosessi ja sen raportit tarjoavat mahdollisuuden osallistua sellaiseen tulevaisuutta koskevaan koulutuspoliittiseen keskusteluun, jossa arvioidaan nykytilaa ja generoidaan tulevaisuuden vaihtoehtoja etenemispolkuineen. Tämän ajatellaan herkistävän huomaamaan uusia näkökohtia, osoittavan vallitsevien käsitysten yksilön oman horisontin ylittävää moninaisuutta ja tuovan realismia sellaisiin näkemyksiin, joissa poliittinen toimija on ilman hyviä perusteita omaksunut poikkeavan tai yksipuolisen kannan.

Suomen Eurodelfoitutkimus toteutetaan kolmivaiheisena prosessina. Tutkimuksen ensimmäisessä vaiheessa lähetettiin kyselylomake 154:1le aikuiskoulutuksen asiantuntijalle. Kyselylomakkeen palautti 127 asiantuntijaa, joten tutkimuksen kato on 18 prosenttia. Kadon vähäiseen määrään ovat vaikuttaneet myönteisesti tutkimuksen kansallisen johtoryhmän kentän tuntemus asiantuntijoita valittaessa, ennakkoyhteydenotto asiantuntijoihin, muistutuskirjeet ja tutkimusaiheen ajankohtaisuus sekä kielteisesti kyselylomakkeen laajuus ja epätäsmällisyys.

Toisessa vaiheessa järjestettiin asiantuntijaseminaari, jossa kyselylomak-keeseen vastanneet asiantuntijat saattoivat esittää täsmentyneet käsityksensä kyselyn tulosten perusteella. Seminaari pidettiin Helsingin yliopiston kasvatustieteen laitoksella lokakuussa 1996. Tutkimuksen kolmannessa vaiheessa kootaan Suomen maaraportin aineistoa, keskustelujen tuloksia ja kansainvälistä vertailuaineistoa käyttäen loppuraportti Suomen aikuiskoulutuksesta eurooppalaisessa kontekstissa.

\section{7 suomalaista aikuiskoulutuksen asiantuntijaa}

Delfoitutkimus korostaa vastaajien tutkimusaihetta koskevan asiantuntemuksen laajuutta ja syvyyttä, koska keskustelu perustuu asiantuntijoiden vastauksista ennalta asetettuihin kysymyksiin. Jotta voidaan saada mahdollisimman luotettavaa tietoa tutkimusaiheesta, on tärkeää, että vastaajilla on tutkimuksen ongelma-alueiden asiantuntemusta. Tutkimuksen johtoryhmä valitsi vastaajiksi aikuiskoulutuksen asiantuntijoita neljästä eri toimijaluokasta ja kuudelta eri toiminta-alueelta.

Poliittiset vaikuttajat (50\%) ovat asiantuntijoita, jotka vaikuttavat koulutuspolitiikan muotoutumiseen jollakin tasolla, jossakin asemassa tai jossakin tehtävässä. Tutkijat (29\%) toimivat tutkimusyksiköissä, yliopistoissa tai opintopalveluyksiköissä, joissa heillä on mahdollisuus järjestelmälliseen reflektointiin kasvatustieteissä tai niiden lähialueilla. Kouluttajiksi (47 \%) määriteltiin asiantuntijat, jotka toimivat käytännön koulutustehtävissä tai opettajankouluttajina. Kommentoijat (34\%) ovat henkilöitä, jotka voivat meedioiden piirissä kriittisinä tarkkailijoina ja voivat tietojensa ja näkemystensä pohjalta vaikuttaa käytännön koulutuspolitiikkaan tai koulutustoimintaan.

Prosenttiluvut kuvaavat toimijaluokkaa edustavien osuutta kaikista vastaajista $(\mathrm{N}=127)$. Mainintoja oli yhteensä 204 kappaletta, koska yksi asiantuntija saattaa edustaa yhtä tai useampaa toimijaluokkaa. Poliittisia vaikuttajia on asiantuntijoiden joukossa eniten ja kouluttajia on lähes yhtä paljon kuin poliittisia vaikuttajia. Tutkijoita on vähiten ja kommentoijia jonkin verran enemmän kuin tutkijoita.

Lomakkeessa kartoitettiin myös vastaajien yhteyksiä tai sijoittumista aikuiskoulutuksen keskeisille toiminta-alueille. Asiantuntijoiden $(\mathrm{N}=127)$ toiminta-aluejakauma oli seuraava: aikuisten ammatillinen koulutus 57 prosenttia, vapaa sivistystyö ja kulttuuritoiminta 45 prosenttia, henkilöstökoulutus 45 prosenttia, nuoren ammatillinen koulutus 35 prosenttia, kasvatus yleisenä kokonaisuutena 35 prosenttia sekä aikuisten peruskoulutus 20 prosenttia. 


\section{ASIANTUNTIJOIDEN AIKUISKASVATUSKÄSITYS}

\section{Aikuiskoulutuksen mahdollisuudet ratkaista aikuisten kokemia ongelmia}

Aikuiskoulutuksen asiantuntijoita pyydettiin arvioimaan, missä määrin aikuiset kokevat ongelmia 22 ongelma-alueella (kts. kuvio 1, tumma palkki). Merkittävimmiksi ongelma-alueiksi arvioitiin työttömyys ja työelämän rakennemuutokset. Ajan kokemisen muutokset (nopeus, stressi) sijoittui kolmanneksi tärkeimmäksi ongelma-alueeksi. Merkittäviksi ongelma-alueiksi arvioitiin myös ammattitaidon puutteet, ihmissuhdeongelmat, epävarmuuden ja elämän tarkoituksettomuuden kohtaaminen sekä politiikkaan kohdistuva epäluottamus ja tietämättömyys. Kyselylomakkeella mainituista ongelma-alueista aikuisten arvioitiin kokevan vähiten liikkumiseen liittyviä ongelmia.

Asiantuntijoita pyydettiin myös arvioimaan, missä määrin aikuiskoulutus voi auttaa ratkaisemaan lomakkeessa mainittuja ongelmia (kts. kuvio 1, vaalea palkki). Aikuiskoulutuksen vaikutusmahdollisuudet arvioitiin selkeästi parhaimmiksi ratkaistaessa ammattitaidon puutteisiin liittyviä ongelmia. Vaikutusmahdollisuudet arvioitiin hyviksi ratkaistaessa pitkälle vietyyn erikoistumiseen, tiedonsaantiin ja työelämän rakennemuutoksiin liittyviä ongelmia, mutta ne arvioitiin vähäisimmiksi ratkaistaessa

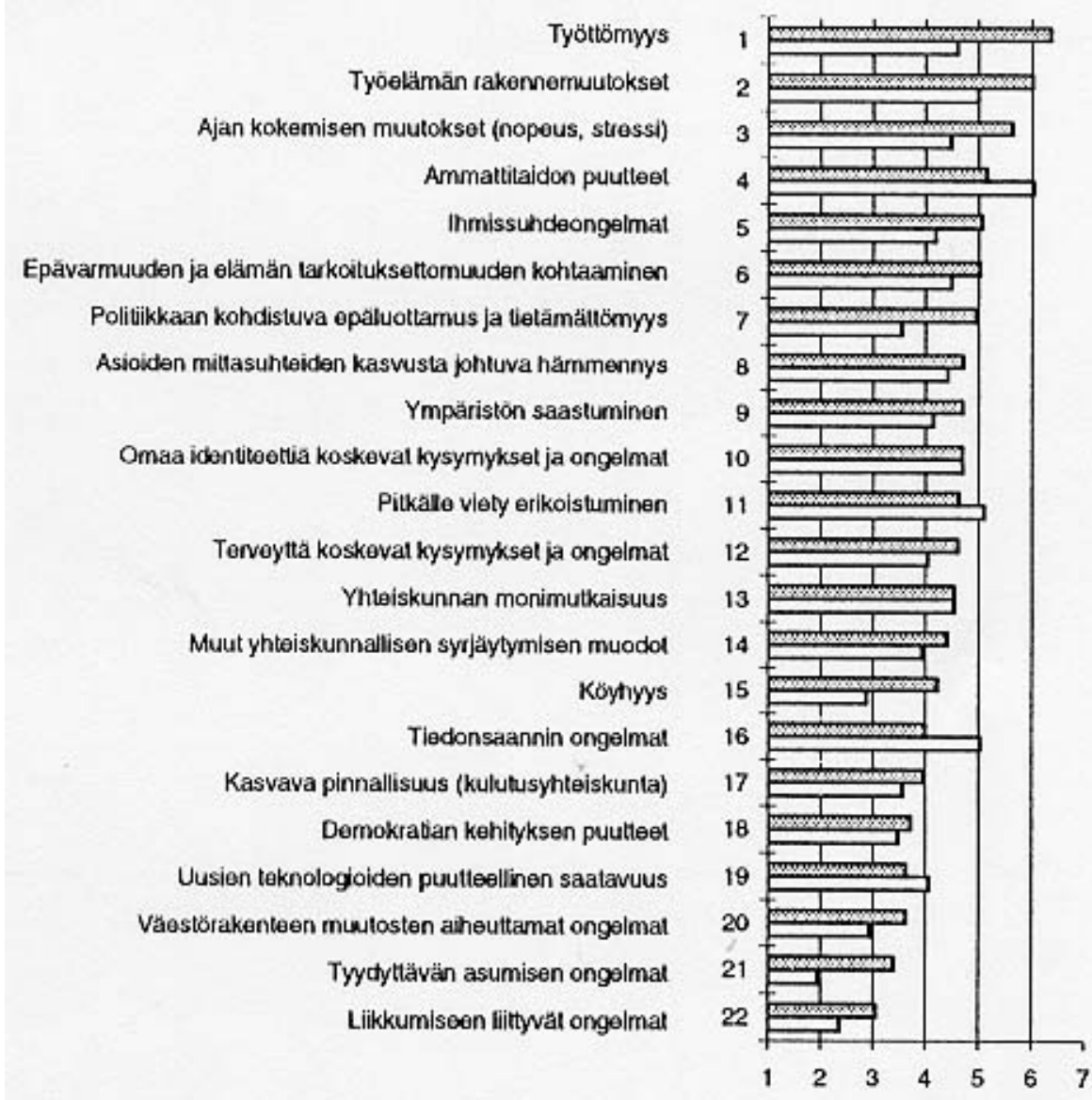

Kuvio 1.Aikuisten kokemat ongelmatja aikuiskoulutuksen mahdollisuudet auttaa niiden ratkaisemisessa. Analyysin tulokset on esitetty suuruusjärjestyksessä ongelma-alueille laskettujen keskiarvojen mukaan; 1 = erittäin vähän, 7 = erittäin paljon. Vastaajamäärä vaihtelee osioittain. N = 125-127. Ks. teksti: palkkien merkitykset. 
tyydyttävään asumiseen ja liikkumiseen liittyviä ongelmia.

Aikuiskoulutuksella on vastaajien mielestä suhteellisesti parhaimmat vaikutusmahdollisuudet ratkaistaessa tiedonsaantiin, ammattitaidon puutteisiin, pitkälle vietyyn erikoistumiseen sekä uusien teknologioiden puutteelliseen saatavuuteen liittyviä ongelmia. Näillä ongelma-alueilla aikuiskoulutuksen vaikutusmahdollisuudet arvioitiin suhteellisesti suuremmiksi kuin aikuisten arvioitiin keskimäärin näitä ongelmia kokevan. Aikuiskoulutuksen vaikutusmahdollisuudet arvioitiin suhteellisesti vähäisimmiksi pyrittäessä ratkaisemaan työttömyyttä, tyydyttävän asumisen ongelmia, politiikkaan kohdistuvaa epäluottamusta ja tietämättömyyttä sekä köyhyyttä.

Erilaiset asiantuntijaryhmät olivat varsin yksimielisiä ongelmien kokemisesta; sekä toimijaluokittain että toiminta-alueittain kaikki ryhmät pitävät työttömyyttä aikuisten eniten kokemana ongelmana. Nuorten ja aikuisten ammatillisen koulutuksen toiminta-alueita edustavien asiantuntijoiden vastauksissa työelämän rakennemuutokselle lasketut keskiarvot nousivat lähelle työttömyyden keskiarvoja. Nämä kaksi ongelma-aluetta kuuluvatkin yhteen, kuten seuraavaksi esiteltävän faktorianalyysin tulos osoittaa.

Faktorianalyysi tehtiin, koska haluttiin saada kokonaiskuva aikuisten kokemista ongelmista ja aikuiskoulutuksen vaikutusmahdollisuuksis- ta näiden ongelmien ratkaisemisessa. Tarkoituksena oli yhdistää osiot laajemmiksi ja samalla luotettavammiksi kokonaisuuksiksi, jotta yksittäisten osioiden merkitys ja osioiden väliset yhteydet saataisiin selville. Faktorianalyysin tuloksena saatiin ongelmille neljä perusulottuvuutta, jotka on esitetty taulukossa 1.

Analyysin mukaan aikuiset kokevat selvästi eniten työelämän ongelmia yksilöllisten ongelmien faktorin sijoittuessa toiselle sijalle. Erikoistumisen ja teknologian ongelmia arvioidaan koettavan yhtä paljon kuin sosiaalisia ongelmia. Asiantuntijoiden käsityksen mukaan aikuiskoulutuksen avulla voidaan vaikuttaa työelämän ongelmien ratkaisemiseen melko paljon. Erikoistumisen ja teknologian ongelmien ratkaisemisessa aikuiskoulutuksen vaikutusmahdollisuudet arvioitiin kohtuullisiksi ja hieman paremmiksi kuin yksilöllisten ongelmien ratkaisemisessa. Aikuiskoulutuksen vaikutusmahdollisuudet muiden sosiaalisten ongelmien ratkaisemisessa arvioitiin melko vähäisiksi. Keskihajonnat osoittavat, että asiantuntijat ovat yksimielisempiä arvioidessaan ongelmien kokemisen määrää kuin aikuiskoulutuksen vaikutusmahdollisuuksia.

\section{Aikuiskoulutuksen tavoitteet ja voimavarojen kohdentaminen}

Asiantuntijoita pyydettiin arvioimaan aikuiskoulutuksen tavoitteiden tärkeyttä sekä voimavarojen kohdentamista näihin tavoitteisiin omalla toiminta-alueellaan. (Kts. kuvio 2, jos-

\begin{tabular}{|c|c|c|c|c|}
\hline \multirow[b]{2}{*}{ Faktorit } & \multicolumn{2}{|c|}{$\begin{array}{l}\text { Aikuisten kokemat } \\
\text { ongelmat }\end{array}$} & \multicolumn{2}{|c|}{$\begin{array}{l}\text { Aikuiskoulutuksen } \\
\text { vaikutusmahdollisuudet }\end{array}$} \\
\hline & KA & KH & KA & KH \\
\hline 1. työelämän ongelmat (F3) & 5.8 & 0.7 & 5.2 & 1.1 \\
\hline $\begin{array}{l}\text { 2. yksilölliset ongelmat (F2) } \\
\text { 3. erikoistumisen ja }\end{array}$ & 5.0 & 0.7 & 4.5 & 1.0 \\
\hline teknologian ongelmat (F4) & 4.1 & 0.9 & 4.7 & 1.2 \\
\hline 4. sosiaaliset ongelmat (F1) & 4.1 & 0.7 & 3.4 & 0.8 \\
\hline
\end{tabular}


Kuvio 2: Aikuiskoulutuksen tavoilteet: tärkeiksikokemisen aste ja voimavarojen kohdentaminen (aika ja työ). Keskiarvot 7-luokkaisella asteikolla ( 1 = erittäin vähän, 7 = erittäin paljon).Vastaajamäärä vaihtelee osioittain, $N=120-127$.

\section{Valkea palkki = voimavaro- jenkohdentaminen, harmaa palkki = aikuiskou- lutuksentavoitteidentärkeys.}

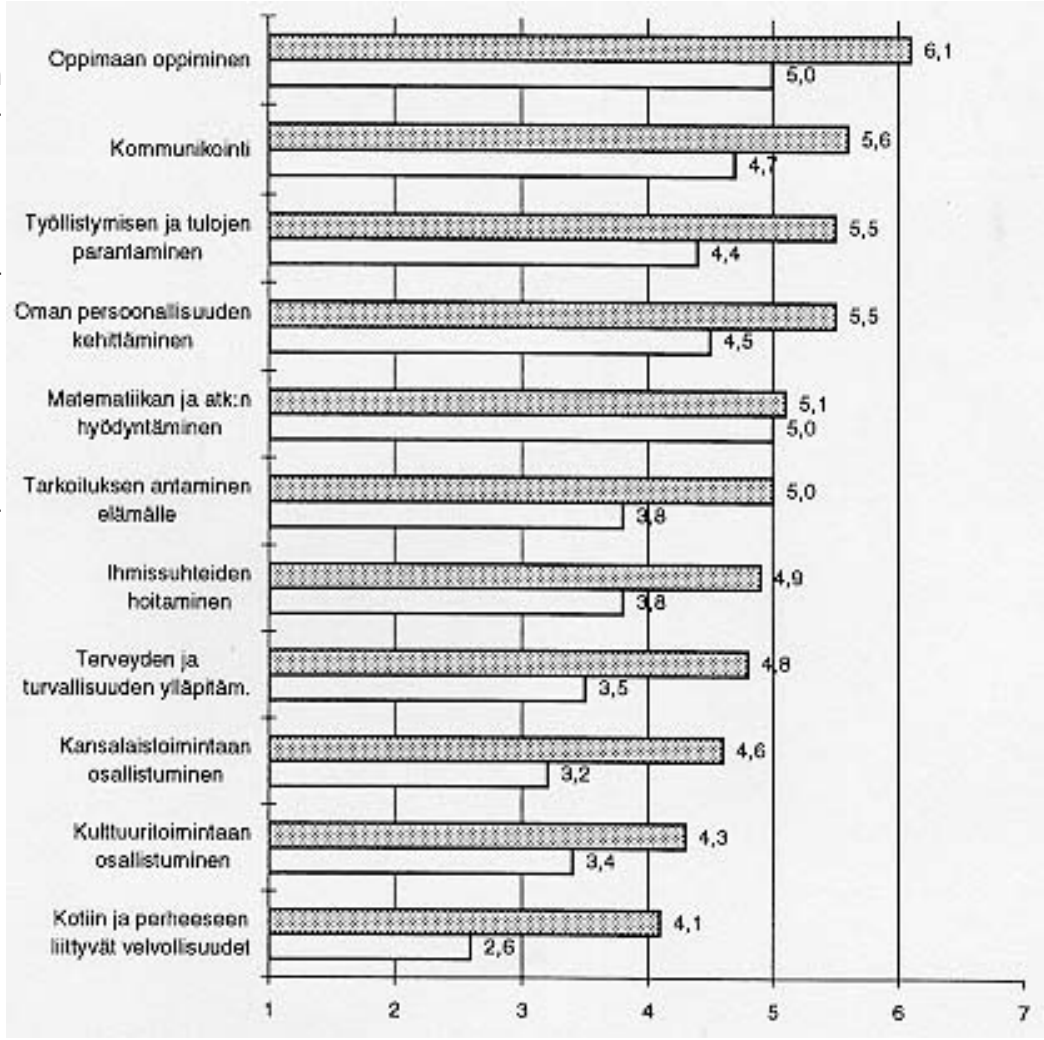

sa tavoitteiden tärkeys on esitetty tummana palkkina ja voimavarojen kohdentaminen vaaleana palkkina.) Aikuiskoulutuksen tärkeimpänä tavoitteena asiantuntijat pitävät selkeästi oppimaan oppimista. Kommunikointi, työllistymisen ja tulojen parantaminen sekä oman persoonallisuuden kehittäminen ovat asiantuntijoiden mielestä seuraavaksi tärkeimpiä aikuiskoulutuksen tavoitteita.

Asiantuntijat arvioivat omalla toiminta-alueellaan kohdistetun eniten voimavaroja (aikaa ja työtä) oppimaan oppimiseen sekä matematiikan, tietojenkäsittelyn ja mikrotietokoneiden hyödyntämiseen. Seuraavaksi eniten voimavaroja arvioidaan panostetun kommunikointiin, persoonallisuuden kehittämiseen sekä työllistymisen ja tulojen parantamiseen. Muiden tavoitealueiden keskiarvot voimavarojen kohdentamisessa ovat pienempiä kuin neljä.

Ainoa aikuiskoulutuksen tavoitealue, jolla tavoitteen tärkeäksi kokemisen aste ja tavoitteen toteuttamiseksi käytetyt voimavarat kohtaavat, on matematiikan, tietojenkäsittelyn ja mikrotietokoneiden hyödyntäminen. Kaikilla muilla tavoitealueilla tavoitteiden tärkeys arvioidaan suuremmaksi kuin niihin käytetyt voimavarat. Suurin ero tavoitteen tärkeyden ja sille kohdennettujen voimavarojen välillä on löydettävissä kotiin ja perheeseen liittyvien velvollisuuksien hoitamisessa, joten kyseessä on laiminlyöty tavoitealue, jonka merkitys saattaa tulla ilmi koulutusta lisättäessä. Asiantuntijoiden käsityksiä tarkasteltiin kokonaiskuvan saamiseksi faktorianalyysin avulla. Faktorianalyysin tuloksena saatiin aikuiskoulutuksen tavoitteille neljä perusulottuvuutta, jotka on esitetty taulukossa 2 .

Aikuiskoulutuksen tärkeimmäksi tavoitealueeksi nousee faktoritasolla persoonallisuuden ja taitojen kehittäminen ja siihen myös investoidaan eniten. Toiseksi tärkein tavoitealue on työllistyminen ja tulojen parantaminen, johon myös kohdennetaan toiseksi eniten voimavaroja. Hyvinvointi sijoittuu molemmissa vertailuissa kolmannelle tilalle yhteiskunnallisen osallis- 
Taulukko 2.Aikuiskoulutuksen tavoitteiden tärkeys ja voimavarojen (ajan ja työn) kohdentaminen tavoitteisiin faktoreille laskettujen keskiarvojen (KA) ja keskihajontojen $(\mathrm{KH})$ perusteella.

Aikuiskoulutuksen tavoitteiden tärkeys

KA KH

$5.6 \quad 0.8$

$5.5 \quad 1.3$

$4.7 \quad 1.2$

$4.4 \quad 1.4$
Voimavarojen (ajan ja työn)

kohdentaminen tavoitteisiin

\section{Faktorit}

1. persoonallisuuden $\mathrm{ja}$

taitojen kehittäminen (F2)

2. työllistyminen ja tulojen parantaminen (F4)

3. hyvinvointi (F1)

4. yhteiskunnallinen

osallistuminen (F3)

\section{KA KH}

$4.8 \quad 0.9$

$\begin{array}{ll}4.6 & 1.7\end{array}$

$3.5 \quad 1.1$

$3.3 \quad 1.5$ tumisen edelle. Voimavarojen kohdentamisen arvioidaan siis vastaavan melko hyvin tärkeysjärjestystä. Voimavarojen kohdentamisen keskiarvot jäävät kuitenkin kaikilla faktoreilla pienemmiksi kuin asiantuntijoiden keskimääräiset arviot tavoitteiden tärkeydestä. Ero on pienin työllistymisen ja tulojen parantamisen kohdalla ja suurin hyvinvoinnin kohdalla. Keskihajonnoista nähdään, että asiantuntijat ovat yksimielisimpiä arvioidessaan persoonallisuuden ja taitojen kehittämistä. Tähän tavoitealueeseen myös kohdennetaan eniten voimavaroja.

\section{Aikuiskoulutuksen tavoitteisiin liittyviä innovaatioita}

Asiantuntijoita pyydettiin arvioimaan, mitä aikuiskoulutuksen tavoitteita varten heidän toiminta-alueellaan oli kehitetty merkittäviä innovaatioita sekä mikä oli ollut näiden innovaatioiden sisältö ja syy. Innovaatio-käsitteellä tarkoitetaan tässä tutkimuksessa Everett Rogersin $(1983,11)$ määritelmän mukaisesti ideaa, käytäntöä tai kohdetta, joka vastaajan käsityksen mukaan on uusi hänen omalla toiminta-alueellaan.

Asiantuntijat mainitsivat innovaatioita syntyneen eniten niillä aikuiskoulutuksen tavoitealueilla, jotka oli arvioitu tärkeimmiksi tavoitealueiksi. Niitä mainittiin runsaasti etenkin oppimaan oppimisessa sekä automaattista tietojenkäsittelyä ja mikrotietokoneita hyödynnettäessä. Yli puolet vastaajista mainitsi merkittäviä innovaatioita syntyneen myös kommunikaatiotavoitteisiin sekä työllistymiseen ja tulojen parantamiseen. Ainoastaan viisi prosenttia vastaajista mainitsi merkittäviä innovaatioita syntyneen kotiin ja perheeseen liittyvien koulutustavoitteiden saavuttamiseen. Seuraavaksi esitetään muutamia esimerkkejä niistä innovaatioista, joita asiantuntijat mainitsivat syntyneen neljällä edellä mainitulla aikuiskoulutuksen tavoitealueella.

Oppimaan oppimista oli pyritty edistämään $\mathrm{mm}$. erilaisin opetusjärjestelyin (verkostoituminen, monimuoto-opetus, avoin oppimisympäristö ja rekonstruktionistinen OPS). Oppimaan oppimisen taitoja oli pyritty kehittämään sekä erillisillä kursseilla että integroituna varsinaiseen opetukseen. Toisaalta oli pyritty tukemaan yksittäisten opiskelijoiden oppimaan oppimista (yksilökohtainen kehittämissuunnitelma, reflektiivisyyteen ohjaaminen, itseopiskelun päiväkirja, portfolio), toisaalta tukea oli pyritty antamaan myös opiskelijaryhmiin kohdistuvien ratkaisujen avulla (yhteistoiminnallinen oppiminen, tutorryhmät). Painotettiin siis opiskelijoiden itsenäisen työn lisäämistä, kuin myös ryhmätoimintaa.

Matematiikan, tietojenkäsittelyn ja mikro-tietokoneiden hyödyntämisessä innovaatioita mainittiin lähes yksinomaan kahdelta viimeksi 
mainitulta alueelta. Vastaajien innovaatiot liittyivät toisaalta tietotekniikkaan välineinä ja infrastruktuurina (uudet ohjelmistot ja tiedonhankintaväylät, internet, sähköposti, multimedia, hypermedia, virtuaaliympäristöt) sekä toisaalta tietotekniikan hyödyntämiseen työssä (puhelin- ja videoneuvottelut, etätyö) ja opetuksessa (telemaattinen opetus, sähköpostiseminaarit, oppimissimulaattorit, tietokoneavusteiset itseopiskeluohjelmat, etäopetus). Tietotekniikkaan liittyviä innovaatioita oli syntynyt $\mathrm{mm}$. verkostoiduttaessa ja yhteistyötä tehtäessä. Innovaationa mainittiin myös Tietoyhteiskunta-Suomi -ohjelma.

Kommunikointiin liittyvinä innovaatioina mainittiin erilaisten teknisten apuvälineiden hyödyntäminen (tietoverkot, internet, sähköposti) ja niiden avulla toteutettu kommunikointi (telemaattinen viestintä). Osa innovaatioista liittyi yksilön kommunikointitaitoihin (itsensä ilmaisu, tiedon hankinta ja käyttö) sekä kommunikoinnin kehittämiseen koulutuksen avulla (prosessikirjoittaminen, aktivoivat opetusmenetelmät, NLP-pohjainen koulutus, kokemusten kautta oppiminen, simulaatiot, radioja tv-kurssit, mediakasvatus, kurssit vuorovaikutustaidoista). Osa innovaatioista liittyi eri osapuolten vuorovaikutukseen (lääkäri-potilas -suhde, kansalaisten ja asiantuntijoiden keskustelun laajennus) ja yhteistyön tekemiseen (tiimityöskentely, verkostoituminen, työssä olevien asiantuntijoiden käyttö koulutussuunnittelussa). Kansainvälistymiseen liittyviä innovaatioita olivat $\mathrm{mm}$. yleinen kielitutkinto, kulttuurintuntemus kielikurssien olennaisena osana ja osallistuminen Erasmus-ohjelmaan.

Työllistymisen ja tulojen parantamiseen liittyvinä innovaatioina mainittiin $\mathrm{mm}$. ammattitutkintojärjestelmä ja työvoimapoliittinen aikuiskoulutusjärjestelmä sekä työelämän uu- det työmuodot, vuorotteluvapaa ja osa-aikalisä. Monet vastaajat pitivät koulutusta ja tutkintoja innovaatioina työllistymisen ja tulojen parantamisessa. Useat innovaatiot liittyivät yrittäjyyden edistämiseen (yrittäjäkoulutuksen ja yrityslähtöisen työvoimakoulutuksen lisääminen, yrityskehittämö sekä työttömien ja nuorten työpajat). Innovaatioina mainittiin myös yhteistyö, verkostoituminen ja avoimien oppimisympäristöjen kehittäminen. Yksilötason innovaatioina mainittiin yksilölliset kehittymisohjelmat, konsultointivalmiuksien kehittäminen ja itsensä työllistäminen. Innovaatioina pidettiin myös täsmäkoulutusta, koulutustarvekartoituksia ja HRD-ohjelmia.

\section{Työelämäkelpoisuus}

Joissakin Euroopan maissa keskustellaan parhaillaan ns. työelämäkelpoisuuteen (start qualifications) liittyvästä koulutuspolitiikasta. Tällä tarkoitetaan, että ihmiset velvoitettaisiin ennen työhön menoa hankkimaan ainakin vähimmäisvaatimukset täyttävä ammattitaito. Samalla joissakin maissa alle 18-vuotiaat nuoret suljettaisiin työmarkkinoilta. Jos nuori työntekijä ei ole hankkinut työelämäkelpoisuutta, työnantajat ja työntekijät olisivat vastuussa siitä, että hän hankkii tällaisen kelpoisuuden. Työttömille tarjottaisiin aloitustason saavuttamiseen tähtäävä koulutusohjelma. Eurodelfoitutkimuksen kyselylomakkeella vastaajia pyydettiin esittämään mielipiteensä tällaisen toimenpiteen toivottavuudesta ja toteuttamismahdollisuuksista.

Kysymykseen, pitäisikö työelämäkelpoisuuden bankeimisvelvollisuus ottaa osaksi Suomen koulutuspolitiikkaa, vastasi suomalaisista asiantuntijoista myönteisesti 74 \%. Eurooppalaisessa aineistossa (Leirman 1995) vastaava tulos oli 71 prosenttia. Vastausten perusteella suo-

\section{Työelämäkelpoisuuden toteuttamismahdollisuudet}

\section{Onko työelämäkelpoisuuden käyttöönotto}

Sellainen politiikea edellyttäisi tarkoitusta

Työelämäkelpoisunden punttumiseen tulisi

tarkoituksenmukaista Suomessa?

varten luotua lainsäädäntöä

kohdistaa sanktioita

\section{Suomi ED95}

$\% \quad \%$

$72 \quad 66$

$75 \quad 87$

$28 \quad 16$ 
malaisilla asiantuntijoilla on suhteellisen suuri kiinnostus ottaa työelämäkelpoisuuden hankkiminen osaksi koulutuspolitiikkaa ja kiinnostus edustaa voimakkuudeltaan eurooppalaista keskitasoa.

Asiantuntijoita pyydettiin ottamaan kantaa myös yksityiskohtaisempiin työelämäkelpoisuutta koskeviin väitteisiin. Työelämäkelpoisuuden hankkiminen auttaisi vastausten mukaan ihmisiä ensisijaisesti kehittämään itseään sekä parantamaan työllisyyttä ja kansantaloutta. Yleiset yhteiskunnalliset ja kulttuuriset taidot nousevat tärkeydessä teknisten ja ammatillisten taitojen edelle. Suomalaiset asiantuntijat painottavat eri osatekijöitä hyvin samalla tavalla kuin Euroopassa yleensäkin.

Työelämäkelpoisuuden hankkimisen toteuttamismahdollisuuksia Suomessa pyydettiin arvioimaan myös asetelmassa esitettyjen kysymysten suhteen. Luvut osoittavat myönteisen vastauksen antaneiden asiantuntijoiden prosentuaalisen osuuden. Vieressä on esitetty Eurodelfoin kansainvälisen raportin (Leirman 1995, 51) vastaavat luvut (ED95).

Suomalaiset asiantuntijat pitävät siis työelämäkelpoisuuden hankkimista periaatteessa toteuttamiskelpoisena, mutta eivät juuri kannata sanktioita niille, joilta tämä kelpoisuus puuttuisi. Sanktioajattelua vierastetaan yleisemminkin tutkimukseen osallistuneissa maissa.

\section{AIKUISKOULUTUSPOLITIIKKA}

Demokratiassa politiikka on kompromissien taidetta. Suomen kaltaisessa monipuoluemaassa suurimmatkaan puolueet eivät voi toteuttaa ohjelmiaan ilman muiden puolueiden yhteisymmärrystä, mikä rajoittaa suurten muutosten toteuttamista. Lisäksi koulutuspolitiikka on erityisalue, jonka piirissä olevista toimijoista suuri osa on poliittisesti sitoutumattomia. Koulutuspolitiikan perusajatuksena on ollut julkisin varoin rahoitettu koululaitos, jonka rinnalla on julkista ja yksityistä yritystoimintaa. Alan laajat järjestöt tekevät omia erityisohjelmiaan ilman tiukkaa puoluepoliittista sidonnaisuutta. Silti valtion ja kunnan poliittisten elinten hyväksymillä laeilla, asetuksilla ja suunnitelmilla on keskeinen asema aikuiskoulutuksen ohjauksessa. Vain opiskelijoiden kysynnän suuntautumista voidaan pitää niitä merkittävämpänä ohjausvälineenä.

\section{Poliittisten elinten tehtävät aikuiskoulutuksessa}

Eurodelfoitutkimuksen kyselylomakkeessa asiantuntijoita pyydettiin arvioimaan poliittisten elinten aikuiskoulutukseen liittyviä tehtäviä, jotka on esitetty taulukossa 3 (sivu 182). Tehtäviä pyydettiin arvioimaan kolmella eri tavalla: 1) kuuluvatko tehtävät poliittisille elimille vai eivät, 2) toteuttavatko poliittiset elimet käytännön toiminnassa näitä tehtäviä vai eivät, 3) miten hyvin poliittiset elimet hoitavat tehtäviä? Taulukossa 3 on esitetty suomalaisten ja muiden eurooppalaisten vastaukset tehtävien kuulumisesta poliittisille elimille sekä tehtävien tulemisesta suoritetuiksi.

Suomalaisten asiantuntijoiden käsityksien mukaan poliittisten elinten tehtävät keskittyvät opetuksen resurssien ylläpitämiseen ja kohdentamiseen. Yli neljä viidennestä vastaajista piti poliittisten elinten tehtävinä taloudellista tukea, rahoitusperusteiden määräämistä, vähemmistöistä ja syrjäytyneistä sekä infrastruktuurista huolehtimista, päällekkäisyyksien ja tuhlauksen ehkäisemistä sekä tarjonnan tasapuolisuuden valvontaa. Tässä suhteessa suomalaisten asiantuntijoiden yhteiskuntakäsitykset poikkeavat vain vähän vastaavista muiden eurodelfoimaiden vastaajien käsityksistä.

Suomen ja muun Euroopan välinen ero tulee kuitenkin esiin tehtäväluettelon vähemmän hyväksytyissä toiminnoissa. Molemmissa aineistoissa toimintamenetelmien asettaminen tärkeysjärjestykseen on arvioitu epäpoliittiseksi tehtäväksi; Suomessa alle viisi prosenttia asiantuntijoista hyväksyisi sen poliittisten elinten tehtäväksi, 16 muun Euroopan maan asiantuntijoista 28 prosenttia pitää tehtävää poliittisena. Suomalaisessa aineistossa on yhteensä kuusi tehtä- 
Taulukko 3.Poliittisten elinten aikuiskoulutukseen liittyvien tehtävien arvioinnit.Asteikko: $1=$ erittäin huonosti ... 7 = erittäin hyvin.

\section{Tehtävä}

1. Taloudellinen tuki

2. Koulutuksen rahoitusperusteiden määrääminen

3. Vähemmistöjä, sosiaalisesti syrjäytyneitä ryhmiä yms. koskevien tärkeysjärjestysten asettaminen

4. Infrastruktuurista (esim. rakennukset, välineet, tukipalvelut) huolehtiminen

5. Päällekkäisyyksien ja voimavarojen tuhlauksen ehkäiseminen

6. Tarjonnan tasapuolisuuden valvonta ja korjaaminen

7. Eri sidosryhmien päätöksentekoon osallistumisesta huolehtiminen

8. Poliittisten periaatteiden toteuttamisen valvonta

9. Saavutettavien tavoitteiden tai päämäärien asettaminen

10. Joidenkin kohderyhmien osallistumisen edistäminen

11. Toiminnan vaikuttavuuden parantaminen

12. Tarjonnan keskinäisen yhteensopivuuden seuraaminen

13. Erityisryhmien koulutustarpeiden arvioiminen

14. Valvonnan välineiden kehittely

15. Koulutuksen sisältöjen asettaminen tärkeysjärjestykseen

16. Laatustandardien määrääminen

17. Kouluttajien ammattitaidon kehittäminen

18. Koulutusohjelmien suunnittelu ja toteuttaminen

19. Toimintamenetelmien (esim. projekti- tai ryhmätyö) asettaminen tärkeysjärjestykseen
Tehtävä kuuluu poliitt. elimelle

\section{SuomiED95 \\ $\% \quad \%$}

$96 \quad 92$

$94 \quad 91$

$89 \quad 86$

$86 \quad 86$

$85 \quad 85$

$83 \quad 77$

$79 \quad 86$

$77 \quad 84$

$75 \quad 66$

$\begin{array}{ll}67 & 79\end{array}$

$62 \quad 70$

$58 \quad 73$

$55 \quad 68$

$43 \quad 71$

$40 \quad 67$

$38 \quad 77$

$29 \quad 69$

$9 \quad 51$

$5 \quad 28$
Poliittinen elin suorittaa tehtävän

\section{SuomiED95}

$\% \quad \%$

$95 \quad 83$

$97 \quad 82$

$69 \quad 59$

$88 \quad 74$

$51 \quad 47$

$56 \quad 46$

$61 \quad 43$

$65 \quad 61$

$76 \quad 57$

$64 \quad 54$

$50 \quad 38$

3840

$55 \quad 46$

$43 \quad 52$

$58 \quad 59$

$38 \quad 77$

$34 \quad 54$

$19 \quad 55$

$19 \quad 35$ vää jäänyt selvän enemmistön mukaan pois poliittisten elinten tehtävistä, eurooppalaisessa aineistossa toimintamenetelmien asettaminen tärkeysjärjestykseen on ainoa. Lisäksi poliittisten elinten tehtävinä ei suomalaisessa aineistossa pidetä koulutusohjelmien suunnittelua ja toteuttamista, kouluttajien ammattitaidon kehittämistä, laatustandardien määräämistä, koulutuksen sisältöjen asettamista tär-keysjärjestykseen ja valvonnan välineiden kehittelyä. Suomalaiset asiantuntijat tekevät siis eurooppalaista keskiarvoa huomattavasti selvemmän eron poliittisten tehtävien ja koulutushenkilöstön professionaalisten tehtävien välille.

Siirryttäessä tarkastelemaan tehtävien suorittamista yleiskuva säilyy, mutta myös tarkentuu. Kenties mielenkiintoisimmat erot suomalaisen ja eurooppalaisen aineiston välillä ovat tehtävissä 9, 14 ja 16. Suomalaisissa arvioinneissa 
kolme neljäsosaa asiantuntijoista pitää tavoitteiden tai päämäärien asettamista poliittisena tehtävänä ja katsoo sen myös tulevan suoritetuksi. Laatustandardien määräämistä ja valvonnan välineiden kehittelyä suomalaisten vastaajien enemmistö ei pidä poliittisena tehtävänä, eikä sitä heidän mielestään myöskään suoriteta. Eurooppalaisessa aineistossa laatustandardien määrääminen ja valvonnan välineiden kehittely ovat hyväksyttyjä poliittisia tehtäviä ja arvioitsijoiden enemmistö myös katsoo niiden tulevan suoritetuiksi. Kärjistäen voisi sanoa, että suomalaiset asiantuntijat odottavat poliitikkojen asettavan päämääriä, mutta eivät halua heidän seuraavan niiden saavuttamista, eivätkä myöskään usko sellaista tapahtuvan. Muiden eurodelfoimaiden asiantuntijat sen sijaan ovat sitä mieltä, että poliittisten toimijoiden tulee valvoa koulutuksen laatua, vaikka nämä eivät syventyisikään tavoitteiden yksityiskohtiin.

Arvioinnit siitä, kuinka hyvin luetellut poliittisten elinten tehtävät tulevat suoritetuiksi, ovat yllättävän matalia. Eurooppalaisessa aineistossa yhtään tehtävää ei arvioida edes asteikon keskimmäisen luvun, neljän, arvoiseksi. Suomalaisessa aineistossa parhaiten hoidetut tehtävät eli infrastruktuurista huolehtiminen (4.4), koulutuksen rahoitusperusteiden määrääminen (4.2) ja taloudellinen tuki (4.0) arvioidaan melko hyvin suoritetuiksi. Näistä vain infrastruktuurista huolehtiminen on kärkisijoilla (keskiarvollaan 3.3 toisena) myös eurooppalaisessa aineistossa. Sijoituksesta huolimatta absoluuttinen ero on suurin. Edellä esitetty ajatus tavoitteiden asetannan ja tulosten seurannan suhteista saa vain puolittain tukea tämän kysymyksen kohdalla. Suomalaisten asiantuntijoiden mielestä päämäärien ja tavoitteiden asettaminen on hoidettu paremmin (3.9) kuin valvonnan välineiden kehittely (3.6) ja laatustandardien määrääminen (3.1). Muissa eurodelfoimaissa kaikki nämä tehtävät on keskimäärin hoidettu melko huonosti.

Eurodelfoilomakkeessa kysyttiin, kenellä pitäisi maassamme olla ylin ministerivastun aikuiskoulutuksesta. Seuraavassa asetelmassa esitetään suomalaisten ja muiden tutkimuksessa mukana olleiden eurooppalaisten asiantuntijoiden vastausten jakaumat.

$\begin{array}{lll} & \begin{array}{l}\text { Suomi } \\ \text { \% }\end{array} & \text { ED95 } \\ & \text { \% } \\ \text { Yhdellä ministerillä } & 55 & 35 \\ \text { Ministerivaliokunnalla } & 18 & 24 \\ \begin{array}{l}\text { Yhteistyötä koordinoivalla } \\ \text { ministerillä }\end{array} & 10 & 21 \\ \begin{array}{l}\text { Kokonaisvastuu pitäisi } \\ \text { jakaa }\end{array} & 17 & 20\end{array}$

Suomalaisten vastaajien enemmistö asettuu yhden vastuullisen ministerin kannalle. Sama vaihtoehto saa eniten kannatusta myös eurooppalaisessa aineistossa (Leirman 1995, 75 - 76). Vastaajilta kysyttiin myös: Miten Teidän käsityksenne mukaan päätöksentekoon osallistuminen ja neuvonanto voitaisiin parhaiten järjestää? Vastaukset jakautuivat seuraavasti.

Säilytetään nykyiset

järjestelyt

$\begin{array}{cl}\text { Suomi } & \text { ED95 } \\ \% & \%\end{array}$

7

Laajennetaan aikuiskou-

lutusneuvoston toimivaltaa 13

Perustetaan uusi aikuiskou-

lutusneuvosto ja jaetaan tehtävät ja valtuudet uudelleen

Perustetaan uusi valvonta

/ohjausneuvosto, jonka

jäseniksi nykyiset

neuvostot tulevat

Muu mahdollisuus

22

13

Suomalaiset ovat hieman tyytyväisempiä nykyisiin järjestelyihin kuin muiden tutkittujen Euroopan maiden asiantuntijat. Enemmistö kuitenkin ehdottaa muutosta. Nykyinen järjestely ei vastaajien mielestä takaa päätöksentekoon riittävän monipuolista asiantuntemusta. 


\section{Aikuiskoulutuksen lainsäädäntö}

Maassamme on pitkään valmisteltu koulutuksen lainsäädännön kokonaisuudistusta, jossa on tarkoitus koota hajanainen lainsäädäntö harvemmiksi, muodoltaan suhteellisen yhtenäisiksi laeiksi ja asetuksiksi. Valtioneuvosto asetti 1995 asiaa edistämään Vilho Hirven johtaman toimikunnan, joka antoi 19.3.1996 mietinnön nimeltä Koulutuksen lainsäädännön kokonaisuudistus (KomM 1996:4). Mietinnössä on ehdotus kahdessa osassa annettavaksi lainsäädännöksi. Ensimmäinen osa käsittää ehdotukset perusopetuslaiksi, lukiolaiksi, laiksi ammatillisesta koulutuksesta, laiksi vapaasta sivistystyöstä, laiksi taiteen perusopetuksesta, laiksi valtion ja yksityisen järjestämän koulutuksen hallinnosta sekä laiksi koulutustoimen eläkkeistä ja muista eduista. Jälkimmäinen osa käsittää yliopistolain ja sen voimaanpanolain.

Lakiehdotukset poikkeavat huomattavasti voimassa olevasta lainsäädännöstä. Normien määrää on uudistuksessa karsittu ja lakeja on vähemmän. Muutenkin ehdotukselle on luonteenomaista pyrkimys keskittyä olennaiseen ja siirtää päätösvaltaa mahdollisuuksien mukaan mahdollisimman lähelle aktiivisia toimijoita.

Eurodelfoin kyselylomakkeella vastaajia pyydettiin valitsemaan 12-kohtaisesta säädösluettelosta neljä merkityksellisintä tai parhaiten tuntemaansa ja arvioimaan niitä kahdellatoista 7-luokkaisella asteikolla. Yli 30 arvioijaa käsitteli lakia työvoimapoliittisesta koulutuksesta, oppisopimuslakia ja lakia ammattitutkinnoista. Vain yksitoista asiantuntijaa arvioi lakia aikuislukioista ja kaksi lakia valtionosuuksista liikunnan koulutuskeskuksissa.

Vapaan sivistystyön puolella myönteisimmät arviot saa laki kansalaisopistosta, jonka perusteella osallistuminen on erittäin helppoa. Laki edistää erinomaisesti laajaa osallistumista ja kriteerit on siinä määritelty erittäin avarasti. Vain osallistujien yhteiskunnallisen aseman parantamisen suhteen vastaajat epäröivät. Laki opetus- ja kulttuuritoiminnan rahoituksesta on saanut kaikkein penseimmän vastaanoton.
Kansanopistolakiin liittyviä korkeita järjestämiskustannuksia lukuunottamatta mistään säädöksestä ei esitetä selvästi kielteisiä arvioita, pääasiassa todetaan voimavarojen niukkuus henkilöstön käytössä.

Osallistujien yhteiskunnallista asemaa arvioidaan parantavan parhaiten lain yleisistä kielitutkinnoista ja lain aikuislukiosta. Vähiten byrokratiaa ja eniten yhteistyötä kentän kanssa liittyy kansalaisopisto- ja opintokeskuslakeihin, joiden perusteella myös osallistuminen on helpointa ja laajinta, kriteerit avarimpia ja yhteiskunnallinen toiminta kriittisintä. Infrastruktuuri koetaan laajimmaksi kansalaisopisto- ja kansanopistolakien perusteella. Parhaiten koetaan toteutuvan kielitutkintolain tavoitteiden.

Mikään ammatillisen koulutuksen säädöksistä ei saa kovin myönteisiä arvioita. Myönteisimmin suhtaudutaan lakiin ja asetukseen ammatillisista koulutuskeskuksista, jotka on valmisteltu yhdessä kentän kanssa. Ne edistävät laajaa osallistumista, luovat laajan infrastruktuurin ja parantavat (varsinkin asetus) osallistujien yhteiskunnallista asemaakin. Epäilevimpiä arvioita saa laki työvoimapoliittisesta koulutuksesta, joka tuottaa byrokratiaa, ei edistä laajaa osallistumista ja jonka kriteerit ja tavoitteiden toteutuminenkin nähdään hieman kyseenalaisena. Äärikielteisiä eivät nämäkään arviot ole. Myös tämän lain nähdään luovan infrastruktuuria ja tarjoavan taloudellisia edellytyksiä.

Ominaisuuksittain tarkasteltuina ammatillisen koulutuksen lainsäädäntö saa parhaat arviot osallistujien yhteiskunnallisen aseman parantamisesta, valmistelusta yhteistyössä kentän kanssa ja osallistumisen edistämisestä. Kaksi jälkimmäistä eivät kuitenkaan ole samaa tasoa kuin vapaan sivistystyön puolella. Heikoimmat arvioinnit tulevat yleensä byrokratiasta ja yhteiskunnallisesta kriittisyydestä; edellistä ammatillisen koulutuksen säädökset aiheuttavat liikaa ja jälkimmäistä liian vähän.

Kun suomalaisen lainsäädännön kokonaisuudistus suhteutetaan edellä selostettuihin tuloksiin, voitaneen tuloksien katsoa tukevan uudistus- 
hanketta. Nykyisiin säädöksiin ei olla kovin tyytyväisiä ja toisaalta yhtä, koko aikuiskasvatuksen kattavaa lakia ei myöskään yleisesti haluta. Useissa maissa sellaisiin lakeihin ollaan melko tyytymättömiä. Ehdotettu ratkaisu, jonka mukaan aikuiskoulutus hajaantuu useampaan sektorikohtaiseen lakiin, ei ole ristiriidassa näiden arviointien kanssa. Toisaalta näyttää kuitenkin siltä, että olipa lainsäädäntö millainen tahansa, sitä tullaan joka tapauksessa kritikoimaan melko ankarastikin. Ilmeisesti voimavarojen ainaisen niukkuuden luoma tyytymättömyys tulee heijastumaan myös lainsäädännön arviointeihin. Tyytymättömyys voitaisiin taata ainoastaan lainsäädännöllä, joka takaa ehtymättömät resurssit ja johtaa myös tavoitteiden täydelliseen saavuttamiseen ilman byrokratiaa ja muita rajoituksia.

\section{AIKUISKOULUTUKSEMME EUROOPPALAINEN ULOTTUVUUS}

Kyselylomakkeessa tiedusteltiin, missä määrin vastaajan toimintakenttä ja hän itse ovat olleet mukana eurooppalaisessa ybteistyössä aikuiskoulutuksen/kasvatuksen alueella. Lisäksi lomakkeessa pyydettiin täsmentämään, miten harjoitettu ybteistyö käytännössä toteutun sekä määrittämään ybteistyötahot (organisaatiot, laitokset, rakenteet, kansainväliset verkostot jne.). Eurooppalaista yhteistyötä on vastausten perusteella huomattavalla osalla suomalaisista asiantuntijoista.

Suomalaiset asiantuntijat ovat erityisen aktiivisia osaamisen vaihdossa, verkostojen kehittämisessä ja yhteisen tarjonnan ja ohjelmien kehittämisessä. Näillä alueilla suomalaiset ovat selvästi eurooppalaista keskitasoa aktiivisempia. Kiinnostava piirre on myös se, että lobbaaminen ja edustaminen on suhteellisen voimakkaasti esillä. Voidaan tietysti kysyä, johtuuko aktiivisuus ensi sijassa siitä, että Suomi on kyselyn aikana ollut vain yhden vuoden EU:n jäsen. Alkuvaiheessa joudutaan luomaan osallistumiselle pohja ja toisaalta myös eurooppalaiset yhteistyötahot saattavat olla keskimääräistä aktiivisempia uusia jäsenmaita kohtaan.
Asiantuntijoilta tiedusteltiin myös, millaista politiikkaa Euroopan viranomaisten pitäisi toteuttaa aikuiskoulutuksen eri osa-alueilla ja millä edellytyksillä, ebdoilla tai normeilla. Kuvio 3 kokoaa vastaajien painotukset EU-politiikan suhteen. Kuviossa esitetään niiden asiantuntijoiden suhteellinen osuus, jotka vastasivat 'kyllä' asianomaiseen kohtaan.

Suomalaiset asiantuntijat näkevät Euroopan viranomaisten mahdollisuudet harjoittaa politiikkaa kaikilla mainituilla alueilla. Voimakkaimmin painottuvat ammatillinen aikuiskoulutus, avoin yliopisto-opetus, nuorten aikuisten ammatillinen koulutus ja monimuoto-opetus. Heikoimmin painottuu maatalouskoulutuksen ja neuvonnan alue. Kaikkiaan suomalaisten vastaajien usko yhteisen EU-politiikan mahdollisuuksiin edistää aikuiskoulutusta on melko optimistinen. Kun verrataan vastaavia koko projektin lukuja Suomen lukuihin, voidaan todeta, että suomalaiset vastaajat ovat kautta linjan arvioineet EU-politiikan mahdollisen merkityksen eurooppalaista keskitasoa korkeammaksi. Sekä suomalaisten että muiden eurooppalaisten arviointien mukaan tärkeimmät poliittisen vaikuttamisen alueet ovat ammatillinen aikuiskoulutus ja avoin yliopisto-opetus, mutta muillakin alueilla on kehitettävissä Euroopan viranomaisten toteuttamaa politiikkaa. (Vrt. Leirman 1995, 85.)

\section{DISKUSSIO}

Eurodelfoin ensimmäisen vaiheen tuloksia selostettaessa on korostunut asiantuntijoiden enemmistön kanta, osin myös Suomen ja muiden tutkimusmaiden yhtäläisyydet. Sen vastapainoksi on sanottava, että useimmissa kysymyksissä on kyllä yllin kyllin myös hajontaa. Jatkoanalyyseissä kiinnitetäänkin erityistä huomiota aikuiskasvatuskäsitysten vaihtelun ja päätyyppien jäsentämiseen. Varsinkin ideologisesti sidonnaiset sosiaaliset ongelmat jakavat vastaajia erimielisiin ryhmiin. Toisen vaiheen seminaarissa tuli esimerkiksi eriarvoistumisesta ja marginalisoitumisesta selkeitä kannanottoja, jotka perustuivat varsin erilaisiin markkinaajattelun ja hyvinvointivaltion malleihin. 
Kuvio 3. Mihin asioihin EU-politiikan tulisi suuntautua?

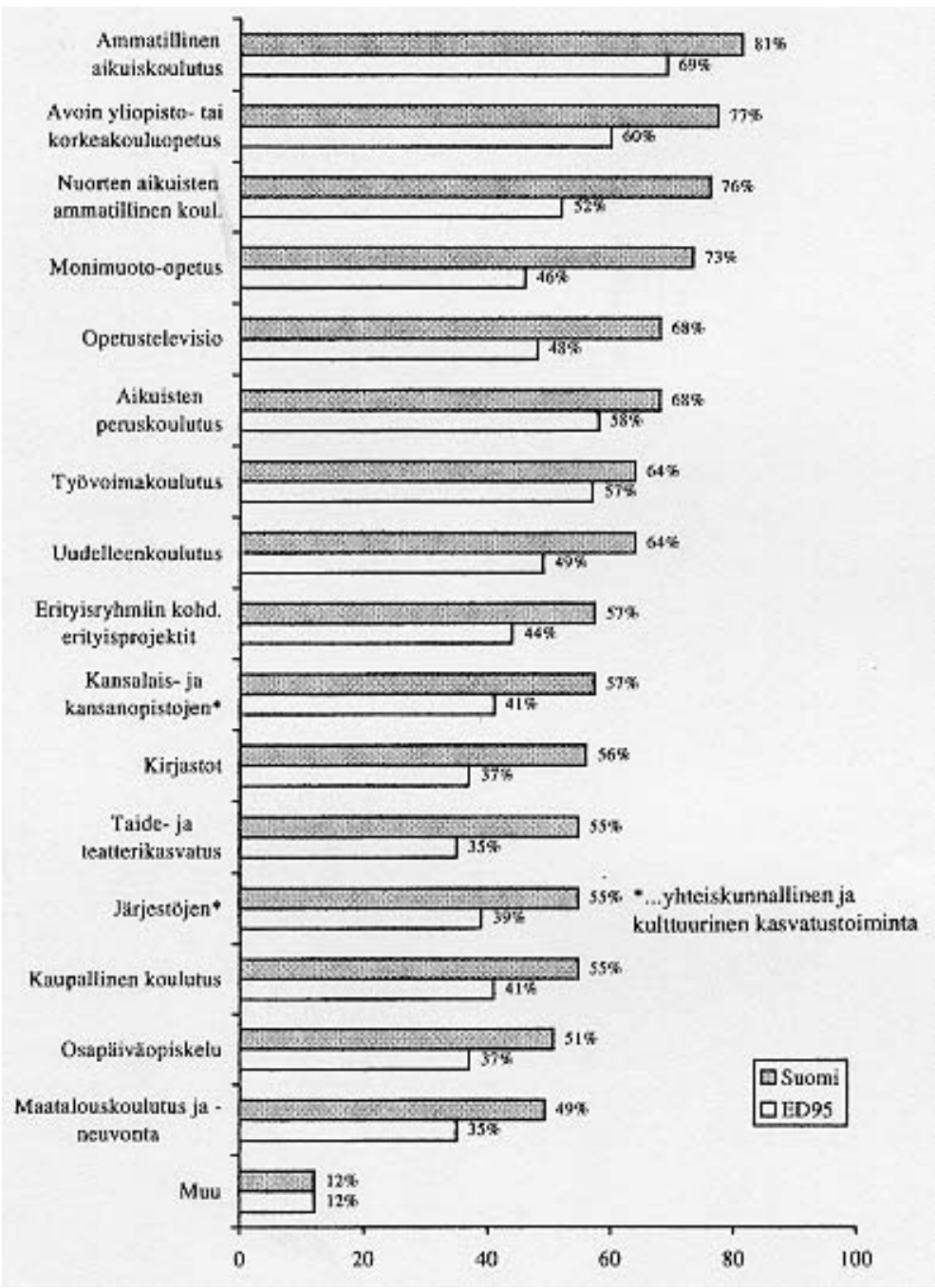

Myös kansainvälisessä tarkastelussa Suomi erottuu muista. Pohjoismaiden tapaan aikuiskoulutuksemme on hyvin kehittynyttä ja asiantuntijat sitoutuneita ratkaisuihin, joita ovat toteuttamassa. Skandinaavinen perinne on kuitenkin maassamme vähemmistöasemassa ja asiantuntijoidemme tapa hahmottaa ilmiöitä poikkeaa myös naapurimme ja kielisukulaisemme Viron näkemyksistä. Näihinkin eroihin palataan hankkeen jatkoraportoinnissa.

Suomen Eurodelfoitutkimuksen asiantuntijaseminaarissa professori Risto Rinne Turun yliopistosta totesi, että koulutus pitäisi riskiyhteiskunnassa ymmärtää entistä syvemmin ihmisen elämänuran yksilöityvien mahdollisuuksien ja selviytymisedellytysten lähtökohtana. Rinteen mielestä on silti epävarmaa, kykeneekö aikuiskoulutus tai elinikäinen oppiminen, koulutuksen jatkuvana reflektiivisenä muotona ymmärrettynä, luomaan mahdollisuuksia identiteetin ja elämänuran luomiseen sekä riskien riittävään hallintaan.

\section{Iähteet}

HAGUE, R. \& HARROP, M. \& BRESLIN, S. (1992) Comparative Government and Politics. An Introduction. 3rd ed. Hound-mills: Macmillan.

JARVIS, P. (ed.) (1992) Perspectives on Adult Education and Training in Europe. Leicester: National Institute of Adult Continuing Education.

Komiteanmietintö 1996:4. Koulutuksen lainsäädännön kokonaisundistus. Helsinki: Opetusministeriö.

LANE, J.-E. \& ERSSON, S. (1994) Comparative Politics. An Introduction and New Approach. Cambridge, MA: Polity Press.

LEIRMAN, W. (1995) Eurodelphi 95 - Future Goals and Policies of Adult Education in Europe. Issues in Adult Education, vol. VI, 11/12.

NURMI, K. E., KONTIAINEN, S. \& TISSARI, V. (1996) Asiantuntijoiden käsitys Suomen aikuiskoulutuksesta. Helsinki: Helsingin yliopiston kasvatustieteen laitos.

ROGERS, E. M. (1983) Diffusion of Innovations. 3. painos. New York: The Free Press.

SACKMAN, H. (1975) Delphi Critique. Expert Opinion, Forecasting, and Group Process. Lexington: Lexington Books.

Artikkeli saapui 1 1.4.1997.Se hyväksyttiin julkaistavaksi toimituskunnan kokouksessa 22.8. 1997. 